African Journal of Biomedical Research, Vol. 10: 175 - 181

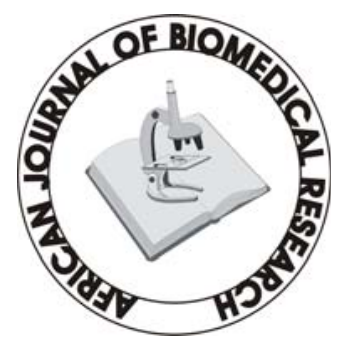

Full-text available at http://www.ajbrui.com http://www.bioline.br/md http://www.ajol.com

Received:

September 2006

Accepted (Revised):

February 2007

Published

May 2007

Full Length Research Article

\title{
Antibacterial and phytochemical studies on twelve species of Indian medicinal plants
}

\section{Jigna Parekh, and Sumitra Chanda*}

Phyochemical, Pharmacological and Microbiological Laboratory, Department of Biosciences, Saurashtra University, Rajkot - 360 005, India.

\section{ABSTRACT}

The aqueous and methanol extracts of 12 plants each belonging to different families were evaluated for antibacterial activity against medically important bacteria viz. B. cereus ATCC11778 , S. epidermidids ATCC12228 , E. aerogenes ATCC13048, P. vulgaris NCTC 8313, S. typhimurium ATCC 23564. The in vitro antibacterial activity was performed by agar disc diffusion and agar well diffusion method. The aqueous extracts were inactive but methanol extracts showed some degree of antibacterial activity against the tested bacterial strains. S. typhimurium was the most resistant bacteria while B. cereus was the most susceptible bacteria. Amongst the plant species screened, methanol extract of Bauhinia variegata bark showed best antibacterial activity.

(Afr. J. Biomed. Res. 10: 175 - 181)

Keywords: medicinal plants, antibacterial activity, aqueous extract, methanol extract

*Address for Correspondence (e-mail) : sumitrachanda@yahoo.com

Abstracted by:

African Index Medicus (WHO), CAB Abstracts, Index Copernicus, Global Health Abstracts, Asian Science Index, Index Veterinarius, Bioline International , African Journals online 


\section{INTRODUCTION}

Nature has been a source of medicinal agents since times immemorial. The importance of herbs in the management of human ailments cannot be overemphasized. It is clear that the plant kingdom harbors an inexhaustible source of active ingredients invaluable in the management of many intractable diseases. Furthermore, the active components of herbal remedies have the advantage of being combined with many other substances that appear to be inactive. However, these complementary components give the plant as a whole a safety and efficiency much superior to that of its isolated and pure active components (Shariff, 2001).

Antibiotic resistance has become a global concern (Westh et al., 2004). There has been an increasing incidence of multiple resistances in human pathogenic microorganisms in recent years, largely due to indiscriminate use of commercial antimicrobial drugs commonly employed in the treatment of infectious diseases. This has forced scientist to search for new antimicrobial substances from various sources like the medicinal plants. Search for new antibacterial agents should be continued by screening many plant families. Recent work revealed the potential of several herbs as sources of drugs (Iwu, 2002). The screening of plant extracts and plant products for antimicrobial activity has shown that higher plants represent a potential source of novel antibiotic prototypes (Afolayan, 2003).

Numerous studies have identified compounds within herbal plants that are effective antibiotics (Basile et al., 2000). Traditional healing systems around the world that utilize herbal remedies are an important source for the discovery of new antibiotics (Okpekon et al., 2004); some traditional remedies have already produced compounds that are effective against antibiotic-resistant strains of bacteria (Kone et al., 2004). The results of this indicate the need for further research into traditional health systems (Romero et al., 2005). It also facilitates pharmacological studies leading to synthesis of a more potent drug with reduced toxicity (Ebana et al., 1991; Manna and Abalaka, 2000).

The need of the hour is to screen a number of medicinal plants for promising biological activity.
In the present work twelve different medicinal plants each belonging to different families was evaluated for their antibacterial properties.

\section{MATERIALS AND METHODS}

Plant material: Fresh plant/plant parts were collected randomly from the semi-arid region of Rajkot Gujarat, India. The details of plant/ plant parts screened, their families, vernacular names and their therapeutic uses are given in Table 1 . The taxonomic identities of these plants were confirmed by Dr. P. S. Nagar, Department of Biosciences, Saurashtra University, Rajkot and the voucher specimen numbers of the plants were preserved. Fresh plant material were washed under running tap water, air dried and then homogenized to fine powder and stored in airtight bottles.

\section{Preliminary Phytochemical Analysis:}

Qualitative phytochemical analysis of the crude powder of the twelve plants collected was determined as follows: Tannins (200 mg plant material in $10 \mathrm{ml}$ distilled water, filtered). A $2 \mathrm{ml}$ filtrate $+2 \mathrm{ml} \mathrm{FeCl}_{3}$, blue-black precipitate indicated the presence of Tannins. Alkaloids (200 mg plant material in $10 \mathrm{ml}$ methanol, filtered). A $2 \mathrm{ml}$ filtrate $+1 \% \mathrm{HCl}+$ steam, $1 \mathrm{ml}$ filtrate +6 drops of Mayor's reagents/ Wagner's reagent/ Dragondroff's reagent, Creamish precipitate/ Browinsh-red precipitate/ orange precipitate indicated the presence of respective alkaloids. Saponins (frothing test: 0.5 $\mathrm{ml}$ filtrate $+5 \mathrm{ml}$ distilled water. Frothing persistence meant saponins were present). Cardiac Glycosides (Keller-kiliani test: $2 \mathrm{ml}$ filterate $+1 \mathrm{ml}$ glacial acetic acid $+\mathrm{FeCl}_{3}+$ conc. $\mathrm{H}_{2} \mathrm{SO}_{4}$ ). Greenblue color indicated the presence of cardiac glycosides. Steroids (Liebermann-Burchard reaction: (200 mg plant material in $10 \mathrm{ml}$ chloroform, filtered). A $2 \mathrm{ml}$ filtrate $+2 \mathrm{ml}$ acetic anhydride + conc. $\mathrm{H}_{2} \mathrm{SO}_{4}$. Blue-green ring indicated the presence of terpenoids. Flavonoids (200 mg plant material in $10 \mathrm{ml}$ ethanol, filtered). A $2 \mathrm{ml}$ filtrate + conc. $\mathrm{HCl}$ + magnesium ribbon. Pink-tomato red color indicated the presence of flavonoids (Harborne, 1973). 


\section{Preparation of extracts:}

For aqueous extraction, $10 \mathrm{~g}$ of air-dried powder was added to distilled water and boiled on slow heat for $2 \mathrm{~h}$. It was then filtered through 8 layers of muslin cloth and centrifuged at $5000 \mathrm{~g}$ for $10 \mathrm{~min}$. The supernatant was collected. This procedure was repeated twice. After $6 \mathrm{~h}$, the supernatant collected at an interval of every $2 \mathrm{~h}$, was pooled together and concentrated to make the final volume one-fourth of the original volume (Parekh et al., 2005). It was then autoclaved at $121{ }^{\circ} \mathrm{C}$ temperature and at $15 \mathrm{lbs}$ pressure and stored at $4{ }^{\circ} \mathrm{C}$.

For solvent extraction, $10 \mathrm{~g}$ of air-dried powder was taken in $100 \mathrm{ml}$ of organic solvent (methanol or ethanol) in a conical flask, plugged with cotton wool and then kept on a rotary shaker at 190-220 rpm for $24 \mathrm{~h}$. After 24 hours the supernatant was collected and the solvent was evaporated to make the final volume one-fourth of the original volume (Parekh et al., 2005) and stored at $4^{\circ} \mathrm{C}$ in airtight bottles.

\section{Microorganisms:}

In vitro antimicrobial activity was examined for aqueous and ethanol extracts from six medicinal plants used by traditional healers. Microorganisms were obtained from National Chemical Laboratory (NCL), Pune, India. Microorganisms were maintained at $4^{\circ} \mathrm{C}$ on nutrient agar slants. Amongst five microorganisms investigated two Gram positive bacteria were $B$. cereus and $S$. epidermidis while three Gram negative bactreria were $E$. aerogenes, $P$. vulgaris and S. typhimurium.

\section{Antimicrobial assay:}

The antimicrobial assay was performed by two methods viz. agar disc diffusion method (Bauer et al., 1966) for aqueous extract and agar well diffusion method (Perez et al., 1990) for solvent extract. The molten Mueller Hinton Agar (HiMedia) was inoculated with the $100 \mu \mathrm{l}$ of the inoculum $\left(1 \times 10^{8}\right.$ $\mathrm{Cfu}$ ) and poured into the sterile Petri plates (Himedia). For agar disc diffusion method, the disc $(0.7 \mathrm{~cm})$ (Hi-Media) was saturated with $100 \mu \mathrm{l}$ of the test compound, allowed to dry and was introduced on the upper layer of the seeded agar plate. For agar well diffusion method, a well was prepared in the plates with the help of a cork-borer $(0.85 \mathrm{~cm}) .100 \mu \mathrm{l}$ of the test compound was introduced into the well. The plates were incubated overnight at $37{ }^{\circ} \mathrm{C}$. Microbial growth was determined by measuring the diameter of zone of inhibition. For each bacterial strain controls were maintained where pure solvents were used instead of the extract. The result was obtained by measuring the zone diameter. The experiment was done three times and the mean values are presented. The results were compared with the standard antimicrobics piperacillin (100 $\mu \mathrm{g}$ /disc) and gentamicin (10 $\mu \mathrm{g} /$ disc $)$.

\section{RESULTS AND DISCUSSION}

The presence of antibacterial substances in the higher plants is well established (Srinivasan, 2001). Plants have provided a source of inspiration for novel drug compounds as plants derived medicines have made significant contribution towards human health. Phytomedicine can be used for the treatment of diseases as is done in case of Unani and Ayurvedic system of medicines or it can be the base for the development of a medicine, a natural blueprint for the development of a drug (Didry et al., 1998).

Successive isolation of botanical compounds from plant material is largely dependent on the type of solvent used in the extraction procedure. The traditional healers use primarily water as the solvent but we found in this study the plant extracts by methanol provided more consistent antimicrobial activity compared to those extracted by water. The results of antibacterial activity of all the 12 plants against the investigated bacterial strains are shown in Table 3. None of the aqueous extracts produced zones of inhibition in the Kirby-Bauer analysis.

This might have resulted from the lack of solubility of the active constituents in aqueous solutions while methanol extract showed some degree of antibacterial activity. Further trials using solvents of various polarities will explore the effects of solvent composition on extract efficacy (Romero et al., 2005).

S. typhimurium was the most resistant bacteria. None of the plant extracts both aqueous as well as methanol extract could inhibit $S$. typhimurium. 
African Journal of Biomedical Research, Vol. 10: 175 - 181

ISSN 1119 - 5096 @ Ibadan Biomedical Communications Group

Table 1. Ethnobotanical information of some traditionally used Indian medicinal plant species selected for antibacterial activity

\begin{tabular}{lllll}
\hline Plant species & Family & Common name & Part used & Therapeutic use \\
\hline Abutilon indicum L. & Malvaceae & Kansaki & Leaves & Rheumatism \\
\hline Acorus calamus L. & Araceae & Vaj & Rhizomes & Flatulence, nervous disorders, diarrhoea \\
\hline Ammannia baccifera L. & Lythraceae & Jal agio & Whole plant & Skin disorders \\
\hline Argyrea nervosa Burm. F. & Convolvulaceae & Samudrasosh & Leaves & Ulcers, anorexia, bronchitis, inflammation \\
\hline Bauhinia variegata L. & Caesalpiniaceae & Kanchnar & Bark skin & Diabetes, goiter, dysentery, diarrhoea \\
\hline Crataeva religiosa Forst. & Cappparidaceae & Varun chaal & Bark skin & Calculi, Flatulence, anaemia, heart complaints \\
\hline Hedychium spicatum L. & Scitamineae & Kapur Kachli & Root & Nausea, bronchial asthama, local inflammation \\
\hline Holarrhena antidysenterica L. & Apocynaceae & Kada Chal & Bark skin & dysentery, diarrhoea \\
\hline Piper nigrum L. & Piperaceae & Chaval & Root & Stimulant, digestive, antispasmodic \\
\hline Plumbego zeylanica L. & Plumbagenaceae & Chitrak & Root & Syphilis, leprosy, piles, rheumatism, leukoderma \\
\hline Psoralea corylifolia L. & Leguminosae & Bavchi & Seeds & Leukoderma, leprosy, psoriasis \\
\hline Saussurea lappa Costus. & Composite & Kuth or uplet & Root & Bronchitis, asthama, leprosy, flatulence \\
\hline
\end{tabular}

Table 2. Preliminary phytochemical analysis of screened medicinal plant species

\begin{tabular}{|c|c|c|c|c|c|c|c|c|}
\hline \multirow[t]{2}{*}{ Plant Species } & \multirow[t]{2}{*}{ Tannins } & \multirow[t]{2}{*}{ Saponins } & \multirow[t]{2}{*}{ Flavanoids } & \multirow[t]{2}{*}{ Steroids } & \multirow{2}{*}{$\begin{array}{c}\text { Cardiac } \\
\text { glycosides }\end{array}$} & \multicolumn{3}{|c|}{ Alkaloids } \\
\hline & & & & & & Mayor's test & Wagnor's test & Dragondroff's test \\
\hline Abutilon indicum L. & - & - & - & + & - & - & - & - \\
\hline Acorus calamus L. & - & - & + & - & ++ & - & + & - \\
\hline Ammannia baccifera L. & + & + & ++++ & + & - & + & +++ & - \\
\hline Bauhinia variegata $\mathrm{L}$. & + & + & - & - & - & - & + & - \\
\hline Crataeva religiosa Forst. & - & - & - & + & - & - & - & - \\
\hline Holarrhena antidysenterica L. & - & + & + & + & - & + & +++ & - \\
\hline Piper nigrum L. & - & - & + & - & - & + & +++ & - \\
\hline Plumbego zeylanica L. & - & + & + & - & - & + & - & - \\
\hline Psoralea corylifolia L. & - & - & ++ & - & - & +++ & +++ & + \\
\hline Saussurea lappa Costus. & + & - & - & + & + & ++ & + & - \\
\hline
\end{tabular}

The phytoconstituents of Argyrea nervosa Burm. F are not reported here

\section{Abstracted by:}

African Index Medicus (WHO), CAB Abstracts, Index Copernicus, Global Health Abstracts, Asian Science Index, Index Veterinarius, Bioline International , African Journals online 
Table 3.

Antibacterial activity of aqueous and methanol extracts of screened medicinal plant species

\begin{tabular}{|c|c|c|c|c|c|c|}
\hline \multirow[t]{2}{*}{ Plant } & \multirow[t]{2}{*}{ Extracts } & \multicolumn{5}{|c|}{ Zone of Inhibition $(\mathrm{mm})^{\mathrm{a}}$} \\
\hline & & B. cereus & $\begin{array}{l}\text { S. epide- } \\
\text { rmidis }\end{array}$ & E. aerogenes & $\begin{array}{l}P . \\
\text { vulgaris }\end{array}$ & $\begin{array}{l}S . \\
\text { typhimurium }\end{array}$ \\
\hline \multirow{2}{*}{ Abutilon indicum L. } & Aq. & - & - & - & - & - \\
\hline & Me. & - & - & - & 1 & - \\
\hline \multirow[t]{2}{*}{ Acorus calamus L. } & Aq. & - & - & - & - & - \\
\hline & Me. & 5 & 6 & 2 & 2 & - \\
\hline \multirow[t]{2}{*}{ Ammannia baccifera L. } & Aq. & - & - & - & - & - \\
\hline & Me. & 6 & - & - & 2 & - \\
\hline \multirow[t]{2}{*}{ Argyrea nervosa Burm. F. } & Aq. & 3 & - & - & - & - \\
\hline & Me. & - & - & - & - & - \\
\hline \multirow[t]{2}{*}{ Bauhinia variegata L. } & Aq. & - & - & - & - & - \\
\hline & Me. & 8 & 7 & - & 3 & - \\
\hline \multirow{2}{*}{ Crataeva religiosa Forst } & Aq. & - & - & - & - & - \\
\hline & Me. & - & 3 & - & 1 & - \\
\hline \multirow[t]{2}{*}{ Hedychium spicatumI L. } & Aq. & - & - & - & - & - \\
\hline & Me. & 4 & 4 & 2 & 2 & - \\
\hline \multirow[t]{2}{*}{$\begin{array}{l}\text { Holarrhena } \\
\text { antidysenterica L. }\end{array}$} & Aq. & - & - & - & - & - \\
\hline & Me. & 6 & 3 & 2 & 2 & - \\
\hline \multirow[t]{2}{*}{ Piper nigrum L. } & Aq. & 3 & - & - & - & - \\
\hline & Me. & - & - & - & 1 & - \\
\hline \multirow[t]{2}{*}{ Plumbego zeylanica L } & Aq. & 3 & - & - & - & - \\
\hline & Me. & 7 & 2 & - & 2 & - \\
\hline \multirow[t]{2}{*}{ Psoralea corylifolia L. } & Aq. & 2 & - & - & - & - \\
\hline & Me. & 7 & - & - & - & - \\
\hline \multirow[t]{2}{*}{ Saussurea lappa Costus. } & Aq. & - & - & - & - & - \\
\hline & Me. & 8 & 2 & - & 2 & - \\
\hline Piperacillin $^{\mathrm{b}}$ & & 18 & 11 & 12 & 20 & 19 \\
\hline Gentamicin $^{\mathrm{b}}$ & & 14 & 22 & 10 & 25 & 25 \\
\hline
\end{tabular}

${ }^{a}$ : Inhibition zones are the mean including disc $(7 \mathrm{~mm})$ and cup borer $(8.5 \mathrm{~mm})$ diameter

${ }^{b}$ : Antimicrobics.- Piperacillin (100 $\mu \mathrm{g} /$ disc); Gentamicin $(10 \mu \mathrm{g} /$ disc)

Aq: Aqueous extract, Me: Methanol extract.

This trend was similar in E. aerogenes, another Gram negative bacteria. On the other hand, the Gram positive bacteria $B$. cereus was the most susceptible bacteria followed by $S$. epidermidis. Various workers have already shown that Gram positive bacteria are more susceptible towards plants extracts as compared to Gram negative bacteria (Lin et al., 1999; Parekh and Chanda, 2006). These differences may be attributed to fact that the cell wall in Gram positive bacteria is of a single layer, whereas the
Gram negative cell wall is multilayered structure (Yao et al., 1995).

Alternatively, the passage of the active compound through the Gram negative cell wall may be inhibited. It is thought that observed differences may result from the doses used in this study. In addition, microorganisms show variable sensitivity to chemical substances related to different resistance levels between strains (Cetin and Gurler, 1989).

Preliminary phytochemical analysis revealed the 
presence of alkaloids (+ve test for Wagnor's) (Table 2) and flavonoids, though the latter was in lesser amount. The other secondary metabolites like tannins, saponins, steroids, cardiac glycosides, etc were present in trace amounts in some of the plants (Table 2). It is not surprising that there are differences in the antimicrobial effects of plant groups, due to phytochemical properties and differences among species.

The investigated plants did not show strong antibacterial activity; however, negative results do not mean absence of bioactive constituents nor is that the plant inactive. Active compound(s) may be present in insufficient quantities in the crude extracts to show activity with the dose levels employed (Taylor et al., 2001). Lack of activity can thus only be proven by using large doses (Farnsworth, 1993). Alternatively, if the active principle is present in high enough quantities, there could be other constituents exerting antagonistic effects or negating the positive effects of the bioactive agents (Jager et al., 1996). With no antibacterial activity, extracts may be active against other bacterial species which were not tested (Shale et al., 1999).

Amongst the plant species investigated, methanol extract of Bauhinia variegata bark showed the most remarkable activity. This plant can be further subjected to isolation of the therapeutic antimicrobials and carry out further pharmacological evaluation.

\section{REFERENCES}

Afolayan, A.J. (2003): Extracts from the shoots of Arctotis artotoides inhibit the growth of bacteria and fungi. Pharm. Biol. 41: 22-25.

Basile, A., Sorbo, S., Giordano, S., Ricciardi, L., Ferrara, S., Montesano, D., Castaldo Cobianchi, R., Vuotto, M.L., Ferrara, L. (2000): Antibacterial and allelopathic activity of extract from Castanea sativa leaves. Fitoterapia 71: 110-116.

Bauer, A.W., Kirby, W.M.M., Sherris, J.C., Turck, M. (1966): Antibiotic susceptibility testing by a standardized single disk method. Am. J. Clin. Pathol. 45: 493-496.

Cetin, T.E., Gurler, N. (1989): Bakterilerin antibiyotiklere duyaarlilik deneyinin yapilmasi. Kukem Dergisi, 12: 2-5.

Didry, N., Dubreuil, L., Trotin, F., Pinkas, M. (1998): Antimicrobial activity of the aerial parts of Drosera pellata Smith on oral bacteria. J. Ethnopharmacol. 60: 91-96.

Ebana, R.U.B., Madunagu, B.E., Ekpe, E.D., Otung, I.N. (1991): Microbiological exploitation of cardiac glycoside and alkaloids from Garcinia kola, Borreria ocymoides, Kola nitida and Citrus aurantifolia. J. Appl. Biotech. 71: 398-401.

Farnsworth, N.R. (1993): Biological approaches to the screening and evaluation of natural products. In: Rasoanaivo P, Ratsimamanga-Urverg S (Eds) Biological Evaluation of Plants with Reference to the Malagasy Flora, Madagascar, pp. 35-43.

Iwu, M.M. (2002): In: Threapeutic Agents from Ehtnomedicine. Ethnomedicine and Drug Discovery. Iwu MM, Wootton JC (Eds) Elsevier Science, Amsterdam.

Jager, A.K., Hutchings, A., van Staden, J. (1996): Screening of Zulu medicinal plants for prostaglandinsynthesis inhibitors. J. Ethnopharmacol. 52: 95-100.

Harbone, J.B. (1973): Phytochemical Methods, London, Chapman and Hill.

Kone, W.M., Kamanzi Atindehou, K., Terreaux, C., Hostettmann, K., Traore, D., Dosso, M. (2004): Traditional medicine in North Cote-d'Ivoire screening of 50 medicinal plants for antibacterial activity. J. Ethnopharmacol. 93: 43-49.

Lin, J., Opoku, A.R., Geheeb-Keller, M., Hutchings, A.D., Terblanche, S.E., Jager, A.K., van Staden, J. (1999): Preliminary screening of some traditional zulu medicinal plants for anti-inflammatory and antimicrobial activities. J Ethnopharmacol. 68: 267-274.

Manna, A., Abalaka, M.E. (2000): Preliminary screening of the various extracts of Physalis angulata (L.) for antimicrobial activities. Spectrum J. 7: 19-125.

Okpekon, T., Yolou, S., Gleye, C., Roblot, F., Loiseau, P., Bories, C., Grellier, F., Frappier, F., Laurens, A., Hocquemiller, R. (2004): Antiparasitic activities of medicinal plants used in Ivory Coast. J. Ethnopharmacol. 90: 91-97.

Parekh, J., Chanda, S. (2006): In vitro antimicrobial activities of extract of Launaea procumbens Roxb. (Labiateae), Vitis vinifera (Vitaceae) and Cyperus rotundus (Cyperaceae). Afr. J. Biomed. Res. 9: 89-93.

Parekh, J., Nair, R., Chanda, S. (2005): Preliminary screening of some folklore medicinal plants from western India for potential antimicrobial activity. Indian $\mathrm{J}$. Pharmacol., 37: 408-409.

Perez, C., Paul, M., Bazerque, P. (1990): An Antibiotic assay by the agar well diffusion method. Acta. Bio. Med. Exp. 15: 113-115.

Romero, C.D., Chopin, S.F., Buck, G., Martinez, E., Garcia, M., Bixby, L. (2005): Antibacterial properties of common herbal remedies of the southwest. J. Ethnopharmacol. 99: 253-257. 
Shale, T.L., Strik, W.A., van Staden, J. (1999): Screening of plants used by southern African traditional healers in the treatment of dysmenorrhoea for prostaglandin-synthesis inhibitors and uterine relaxing activity. J. Ethnopharmacol. 64: 9-14.

Shariff, Z.U. (2001): Modern Herbal Therapy for Common Ailments. Nature Pharamcy Series Vol.1, Spectrum Books Ltd., Ibadan, Nigeria in Association with Safari Books (Export) Ltd. UK, pp 9-84.

Srinivasan, D., Nathan, S., Suresh, T., Perumalsamy, O. (2001): Antimicrobial activity of certain Indian medicinal plants used in folkloric medicine. J. Ethnopharmacol. 74:217-220.

Taylor, J.L.S., Rabe, T., McGraw, L.J., Jager, A.K., van Staden, J. (2001): Towards the scientific validation of traditional medicinal plants. Plant Growth Regul. 34: 23-37.

Westh, H., Zinn, C.S., Rosdahl, V.T., Sarisa Study Group (2004): An international multicenter study of antimicrobial consumption and resistance in Staphylococcus aureus isolates from 15 hospitals in 14 countries. Microbial Drug Resistance 10: 169-176.

Yao, J., Moellering, R. (1995): Antibacterial agents. In: Manual of Clinical Microbiology, Murray P, Baron E, Pfaller M, Tenover F, Yolken R (Eds), ASM, Washington DC, pp.1281-1290. 